\title{
Shaping the forms of tall buildings in light of research and analyses associated with the influence of wind
}

\author{
Kształtowanie formy budynków wysokich \\ w świetle badań i analiz związanych z oddziaływaniem wiatru
}

ROMAN PARUCH *

DOI: https://doi.org/10.17814/mechanik.2017.7.71

\begin{abstract}
The development of the construction of high-rise buildings that is associated with the building of taller and taller buildings with atypical shapes leads to the search for alternative and, at the same time, inexpensive design solutions that us to limit adverse aerodynamic influences. Representative conditions regarding the form of tall buildings that allow the reduction of complicated aerodynamic phenomena that occur around a structure have been presented in the paper.
\end{abstract}

KEYWORDS: the architecture of tall buildings, tall building, influence of wind, wind tunnel analysis

Depending on the question analyzed, the definition of a tall building may take different forms. In the area of external loads acting on the load bearing elements of the elevation objects, an extreme building is an appropriate term. The scale and range of forces acting directly on the building and the phenomena occurring in its immediate vicinity often have no simple reference to source materials such as industry standards [1] or design and implementation guidelines. Geometry of the extreme building is inseparably linked to its significant height, reaching up to $1000 \mathrm{~m}$, from the surface. This height is the reason for the generation of significant loads, often exceeding the standard assumptions developed for standard engineering design projects. The design problem of tall building is especially related to the reduction of horizontal displacements of the building and its spatial rigidity, suitable foundation and resistance to dynamic wind or seismic forces.

The global trend, seen in Asia and the Middle East, related to the design and construction of ever-taller buildings, requires designers to determine the actual wind loads that correspond to the exact location of tall building.

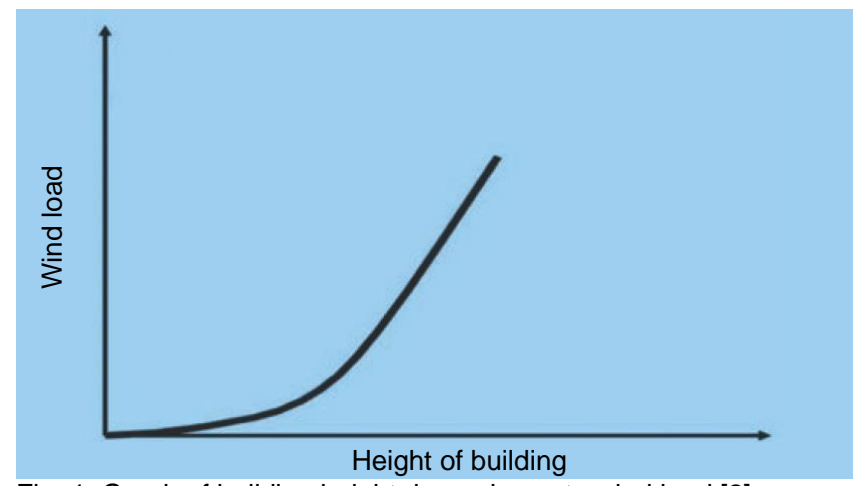

Fig. 1. Graph of building height dependence to wind load [2]

\footnotetext{
* Mgr inż. Roman Paruch (rparuch@pk.edu.pl) - Instytut Projektowania Budowlanego, Politechnika Krakowska
}

Among all the forces acting on the object in question, the wind load is of fundamental importance. The correlated relationship between the height of the building and the size of climatic impacts (in the form of aerodynamic phenomena) is presented in fig. 1 [2].

The key design challenge associated with running loads is the proper selection of the structural system while optimizing its geometric dimensions. Existing construction solutions differ primarily by the transmission of forces horizontal from wind and seismic - to foundations. Realization of a tall building cannot be based solely on the adoption of a very rigid structure that responds to external operating loads. The researches and analyzes of basic aerodynamic problems [3, 4] and dependencies presented in paper [5], make it possible to classify the geometry of the structural system. It is necessary to supplement the presented analyzes with studies describing the reduction of unfavorable aerodynamic influences through architectural and geometrical changes in the cross-section of the building [6-8].

Research and analysis of the influence of wind phenomena on the tall building

Contemporary high-rise buildings break the stereotype of a skyscraper as a glazed cuboid. Increasingly knowledge of the aerodynamics and phenomena surrounding extreme buildings allows for the realization of complex forms that often refer to tradition, religion or history. L.H. Sullivan, a famous Chicago architect, recognized as the forerunner of modern tall buildings, used to say: The force and power of altitude must be in it the glory and pride of exaltation must be in it. It must be every inch a proud and soaring thing, rising in sheer exultation that from bottom to top it is a unit without a single dissenting line, that it is the new, the unexpected, the eloquent peroration of most bald, most sinister, most forbidding conditions [9].

The static-strength verification of the building's load bearing elements according to Eurocode 1 [1] for elevation objects must be backed by two research methods: aerodynamic tunneling studies and analysis of real-time data from real-time measurement systems [10]. The reference height specified in standard [1] and the block diagram shown in fig. 2, for high-altitude objects, allow the determination of load areas of tall buildings along the height.

Professor A. Flaga developed in his studies basic concepts of air flow around the building, such as the boundary layer, geometric and aerodynamic position of the shear layer, aerodynamic geometric parameters, circulation of the stream around the building. 


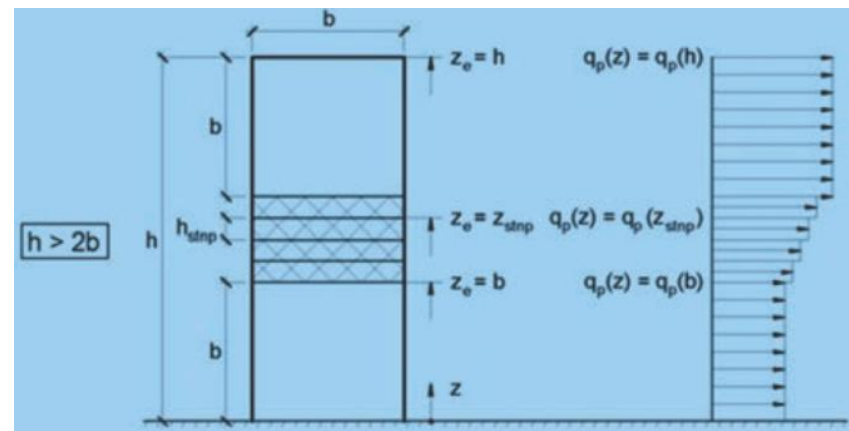

Fig. 2. Graphical height reference block diagram, illustrating load areas according to standard [1]

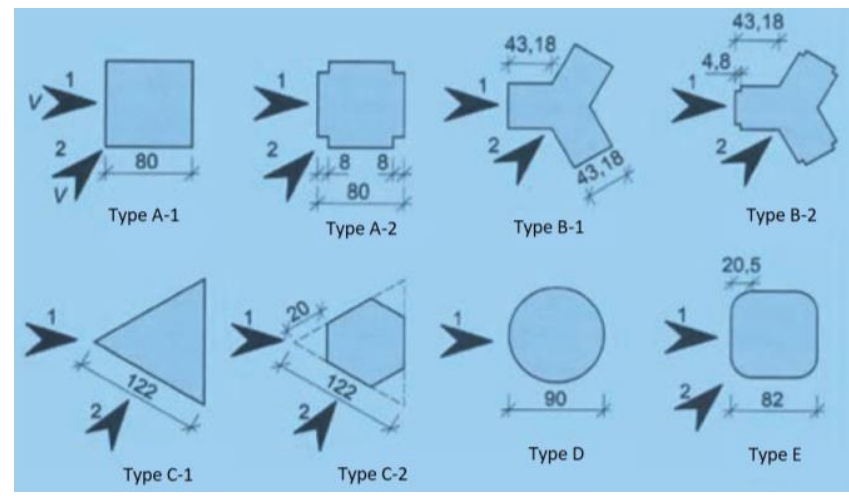

Fig. 3. Shapes and directions of loading of tested cross-sections [8]

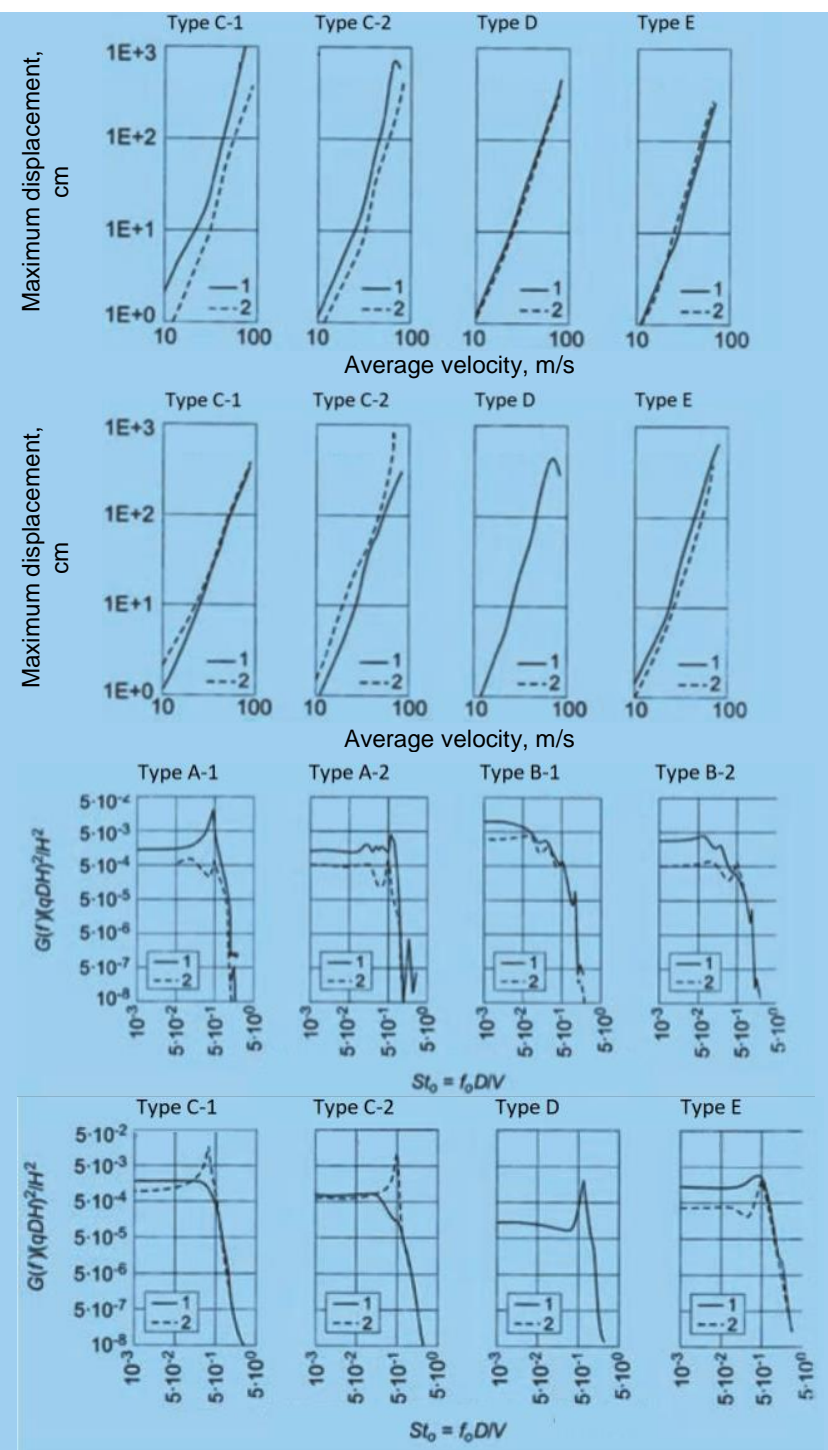

Fig. 4. Correlations related to change in cross-section as a response to the whole building [8] (Sto - kinematic number of Strouhal)
The graphical description of the phenomena surrounding the building is presented graphically in [8]. Results of the research conducted in the wind tunnels by $\mathrm{H}$. Hayashide and $\mathrm{Y}$. Iwasa on four architectural forms, including the subsequent modification of their crosssectional baseline, showed a significant change in the aforementioned parameters. The cross-sections are shown in fig. 3 .

The obtained results showed a clear correlation between the modified shape of the cross-section and the airflow around the tall building. Results and correlations dependencies are illustrated on diagrams in fig. 4.

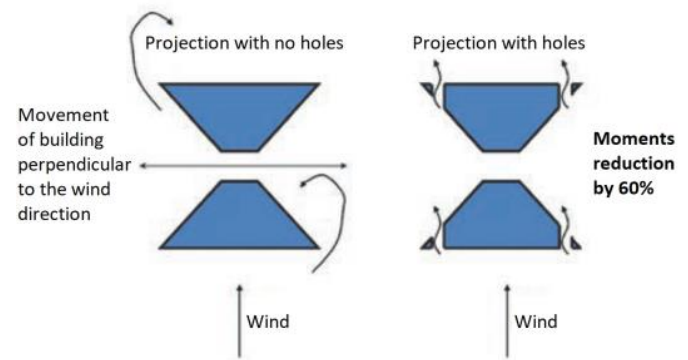

Fig. 5. Diagrams of the examined shapes of the horizontal projection of the building [2]

\section{Realizations of tall buildings in relation to presented studies and analyzes}

The presented aerodynamic conditions along with the results of the research are reflected in the realizations of modern tall buildings. The first representative facility is the Taipei 101, 509 meters high, built in Taiwan. Geometry of the vertical cross-section of the building belongs to the group of complex forms, which in the studies [3] obtained low assessments of the quality of construction. In the aerodynamic tunnel, [2] the influence of changes in the cross-section of geometric projection of the building as an architectural form to the aerodynamic phenomena and the wind load was investigated. Introduction to the original geometry of the building (cuboid) of corner modifications reduced the aerodynamic phenomena by $25 \%$ (fig. 6 ).

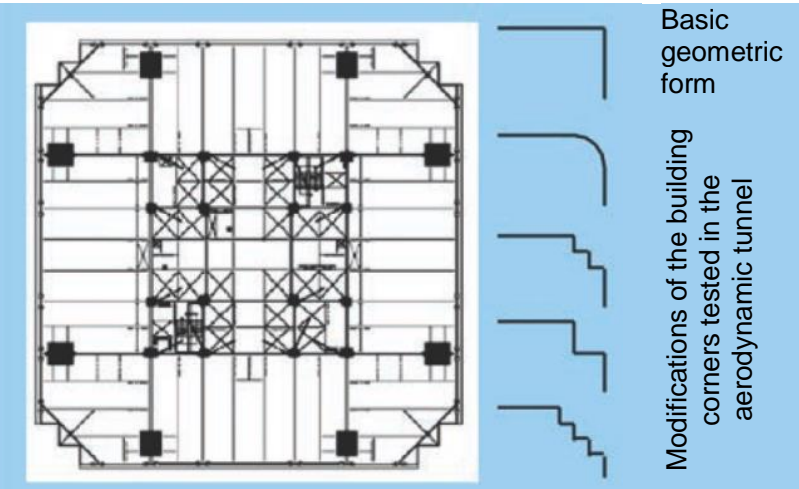

Fig. 6. View of the typical storey of the Taipei 101 building and modifications of the corners of the building examined in the aerodynamic tunnel [2]

Noteworthy for the study, [6, 8, 9] is the Pearl River Tower, $310 \mathrm{~m}$ high, located in Guangzhou, China, designed by SOM. The cross-section of this building has been modified to allow wind flow through its cross-section. The solution not only reduced the scale of aerodynamic impacts on the building, but also provided additional electricity produced by wind turbines in the building. The state of the building completed in 2012 and the aerodynamic conditions are shown in fig. 7. 
a)

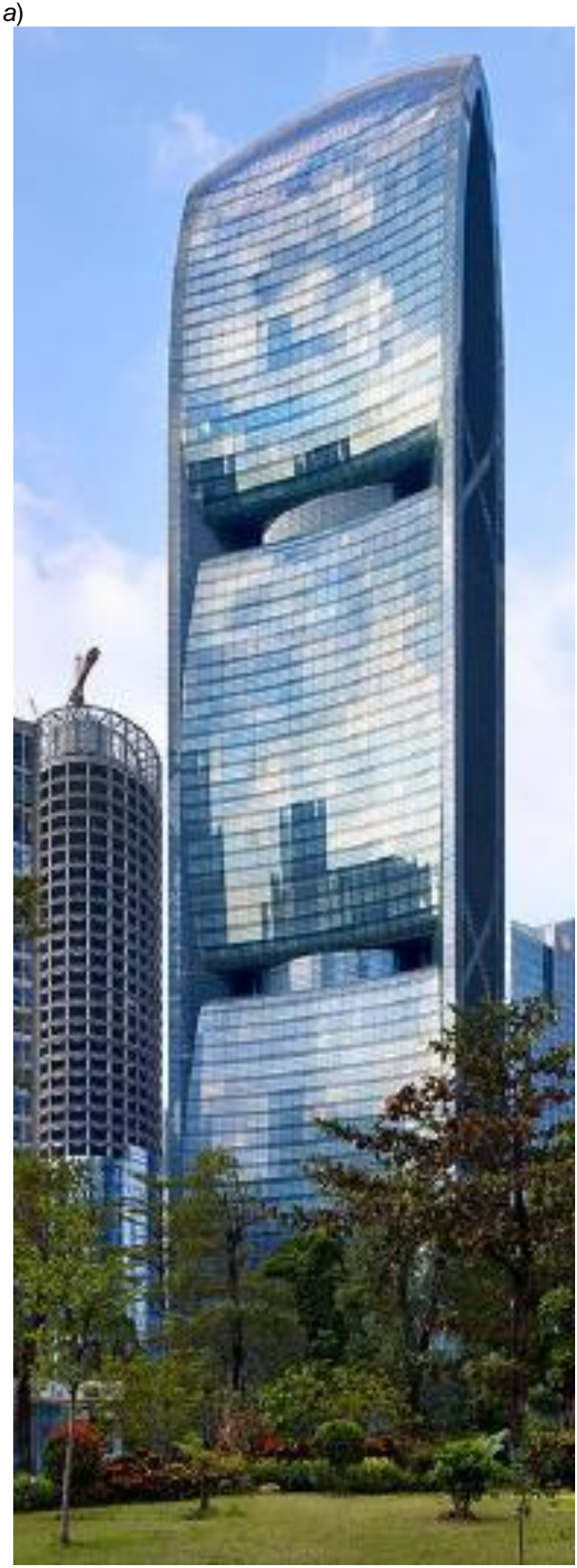

b)

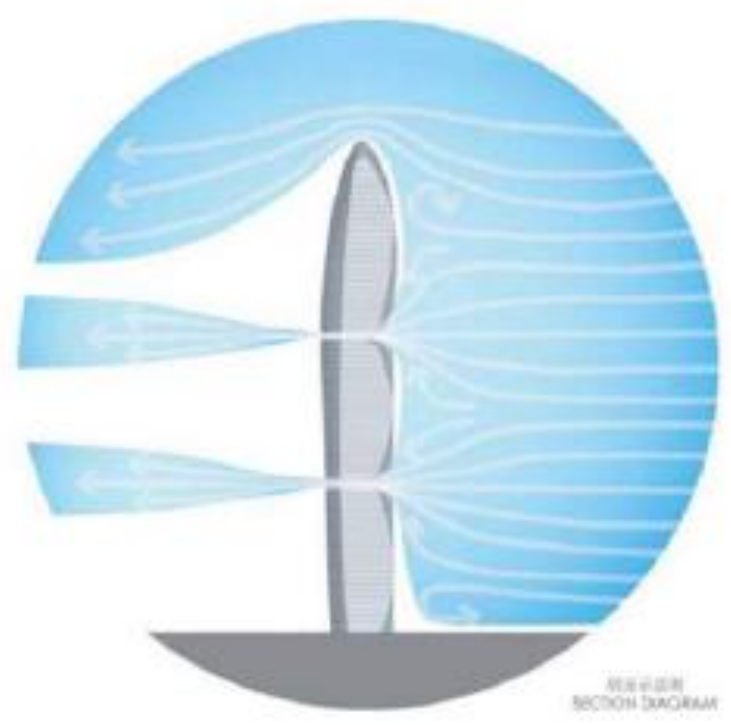

Study of prevailing wind directions

c)

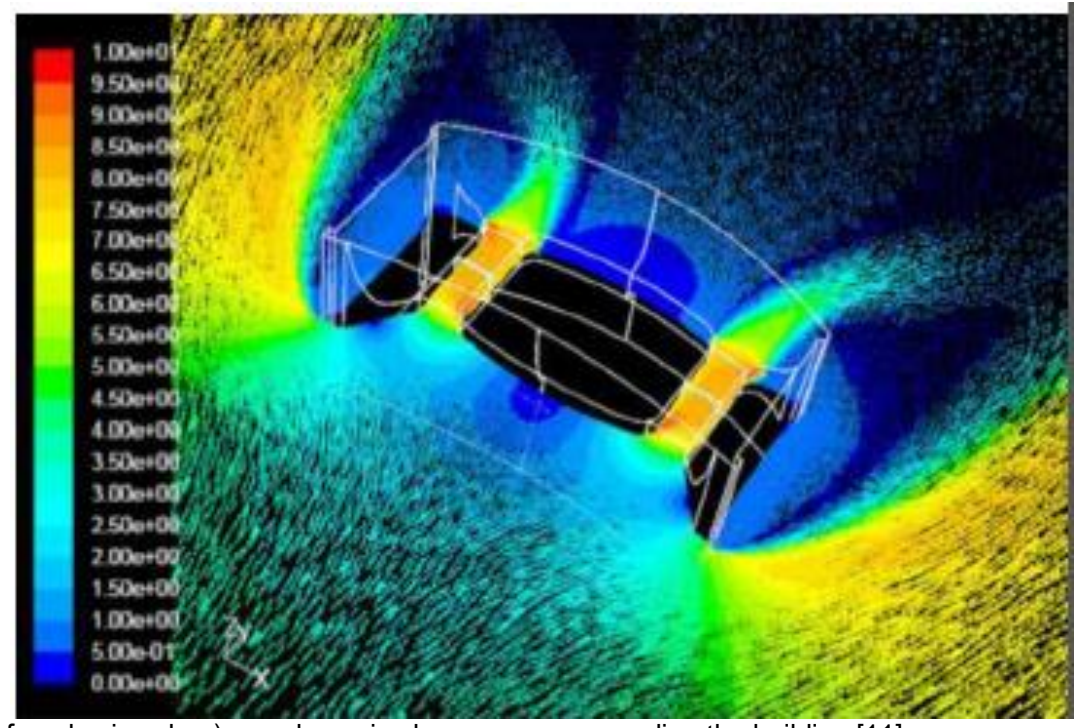

Fig. 7. Pearl River Tower in Guangzhou: a) Southern façade view, b-c) aerodynamic phenomena surrounding the building [11]

\section{Conclusions}

Presented results of the research and analysis of the aerodynamic phenomena resulting from the change in geometry of the cross-section of tall building constitute an effective solution - not only theoretical but also practical, successfully applied in the examples presented in the paper. The realization of ever-increasing buildings of unusual shapes forces the search for alternative methods of limiting the adverse phenomena caused by wind loads and seismic forces. The existing building systems of extreme buildings, supported by special stabilizing mechanisms, ensure the proper transfer of external influences, however, the future of high-rise buildings will be closely linked to alternative architectural and structural solutions that optimize the cost-effective structures.

\section{REFERENCES}

1. PN-EN 1991-1-4. Eurokod 1. Oddziaływania na konstrukcje. Cześć 1-4: Oddziaływania Ogólne - Oddziaływania wiatru.

2. Irwin P.A. "Wind issues in the design of tall buildings". RWDI, Los Angeles Tall Building Structural Design Council, 2010.

3. Rychter Z. „Wpływ kształtu wieżowców na jakość konstrukcji”. Architecturae et Artibus. 2 (2013).

4. Lipiecki T. „Oddziaływanie wiatru na budynki wysokie w świetle badań własnych i ujęć normowych”. Budownictwo i Architektura. 12, 2 (2013): pages 143-150.

5. Paruch R. "Impact of wind on tall buildings from the perspective of the development of architectural forms and structural systems". Mechanik. 7 (2016).

6. Kwok K.C.S. "Aerodynamics of tall buildings". A State of the Art in Wind Engineering. New Delhi: Wiley Eastern Limited, 1995.

7. Melbourne W.H. "Bluff body aerodynamics for wind engineering". International Conference on Wind Engineering. New Delhi, 1995.

8. Hayashida H., Iwasa Y. "Aerodynamic shape effects of tall building for vortex induced vibration". Kyoto, Japan, 1988.

9. Sullivan L.H. Lippincott's Magazine. 1896.

10. Antecki P., Wdowicki J. „Budynek D-Wang Tower - konstrukcja i obliczenia”. Inżynieria i Budownictwo. 3 (2011).

11. SOM: www.som.com. 